\title{
Instrumentation for in-situ foundation investigation in Lagos, South West (SW) Nigeria
}

\author{
Adebisi N. O.* and Fatoba J. 0. \\ Department of Earth Sciences, Faculty of Science Olabisi Onabanjo University, Ago-iwoye, Ogun State, Nigeria.
}

In areas underlain by stratified rocks, it is difficult to obtain undisturbed samples at depth for satisfactory geotechnical results when analysed in the laboratory. Considering the complexity of its subsurface geology, a study on in-situ geotechnical exploration tool for foundation investigation in Lagos was conducted. Layer apparent resistivity ( $\rho$ a) was measured with ABEM SAS 300 Terrameter using Schlumberger array at $A B / 2$ ranging from 1.0 to $50.0 \mathrm{~m}$. The resistivity curves were interpreted using the partial curve matching techniques, and computer iteration with RESIST software. Cone penetration test (CPT) was conducted with penetrometer unit of a cone apex angle $60^{\circ}$ over an area of $10 \mathrm{~cm}^{2}$. Winch and push rods were used to force the cone into the ground, while penetration resistance $\left(q_{c}\right)$ was read from pressure gauge at 5 locations. Plots of $q_{c}$ against depth of penetration were made in reverse order to obtain point resistance-depth curves. Allowable bearing capacity (ABC) of beds at depths of interest was estimated using Meyerhoff's formula in $\mathrm{kN} / \mathrm{m}^{2}$. The geological conditions to depth of about $13 \mathrm{~m}$, from Shomolu to Ajah revealed a maximum of 5 layered soil types. Across the study area, the fourth layer of 0.5 to $1.1 \mathrm{~m}$ thickness range with minimum resistivity of $17 \Omega \mathrm{m}$, constitutes the competent layer. Although, the resistivity value is characteristic of organic clay/coarse sand, the ABCs for shallow foundations, regardless of the width at depths of between 4.25 and $9.75 \mathrm{~m}$ are 288.9 and $675 \mathrm{kN} / \mathrm{m}^{2}$, respectively. The geoelectric sections revealed broad composite nature of the underlying strata, while the CPT curves furnished information about the lithology variability of the underlying soils.

Key words: Geotechnical, resistivity, Lagos, foundations, penetration resistance.

\section{INTRODUCTION}

Apart from cost and difficulty of recovering undisturbed samples to provide satisfactory geotechnical information for site investigation in areas underlain by stratified rocks, instrumentation is another factor. For this particular reason, little or no attention has been paid to in-situ acquisition of accurate geotechnical information on the nature of subsurface conditions in such areas prior to construction project. The engineers also resolved that laboratory tests of undisturbed soil samples represent unconventional tests on a soil element, which happens to remain in the ground. It is obvious that result of tests on undisturbed samples cannot be scaled in any way to predict directly the behavior of a full scale construction (Carter and Bently, 1991).

Lagos metropolis is underlain by stratified sedimentary deposits with a high degree of lithologic variability (Onwuka, 1990). This factor as emphasized by Abam and George (1997) and Abam and Okogbue (1997), made the 
depth to foundation in such areas to remain unclarified. This paper presents the use of geoelectrical measurement and in-situ penetrometer as instrumentation for establishing soil profile, and predicting foundation conditions in a circumstance of an area underlain by stratified rocks. By these methods, surfacial geological mapping and identification of underlying rocks in the area are no longer required due to rapidity in urban development.

Research work on foundation investigation for structures, which made use of undisturbed samples or indirectly determined ground conditions for instance, Olorunfemi and Mesida (1987), Olorunfemi et al. (2000) e.t.c., were carried out in areas underlain by basement rocks. Olayinka and Oyedele (2001) employed electrical resistivity method only to assess ground conditions in a proposed lbadan-llorin dual carriageway. This is definitely inadequate as geotechnical testing of samples either on the field or laboratory was not involved. Adebisi and Oloruntola (2005) showed much reliable results for recommendations on foundation design for a building underlain by basement rocks. In the study, vertical electrical sounding (VES) and horizontal resistivity profiling (HRP) were combined with cone penetrometer test (CPT) data in defining appropriate ground conditions.

Oyedele and Olorode (2010) revealed differential settlement of various degrees in several buildings at Medina Estate, Gbagada, and Lagos State. The site under investigation was found to be underlain by clay occurring from the ground level to over $20 \mathrm{~m}$ in many parts of the site. Although, sand bed of appreciable thickness occur at depth range of 14 to $25 \mathrm{~m}$ and above in some parts of the site, soils at shallow depths consist of extensive layer of extremely low shear strength formation and a corresponding high volume of compressibility potential. Oyedele and Okoh (2011) correlated geophysical and geotechnical data to define subsoils at Magodo Phase II Lagos, Nigeria. The generated geo-electric layers showed that the subsurface comprises topsoil, sandy clay (14.33 to $37.3 \mathrm{~m})$, sand (3.35 to over $70 \mathrm{~m})$, clay (22.4 to $43.89 \mathrm{~m}$ ) and sand (27.64 to $55.89 \mathrm{~m})$. However, plots of the penetration resistance versus depth showed competent layers at 14 and $18 \mathrm{~m}$.

Approach to site investigation for structures using insitu testing methods, has not been sufficiently employed in areas underlain by sedimentary rocks. The aim of this study is to employ in-situ means of information acquisition regarding subsoil conditions for foundation design instead of expensive and time-consuming sampling, which normally yield unreliable results. Careful interpretation geoelectrical data, and its correlation with penetration resistance - depth curves is expected to provide better subsurface picture capable of revealing heterogeneity and anisotropic nature of the formation. Furthermore, estimation of allowable bearing pressures is very possible, under circumstances beyond the capabilities of laboratory methods using Meryerhof's formula.

\section{Physical setting and geology of the study area}

Lagos area is located in Southwestern part of Nigeria within approximately between latitudes $6^{\circ} 22^{\prime} \mathrm{N}-6^{\circ} 52^{\prime} \mathrm{N}$ and longitudes $2^{\circ} 42^{\prime} \mathrm{E}-3^{\circ} 42^{\prime} \mathrm{E}$ (Figure 1). According to Odumosu (1992), the southern boundary of Lagos is formed by the $180 \mathrm{~km}$ Atlantic Coastline, while its northern and eastern boundaries are sheared with ljebu towns and villages in the tropical region. On the western side, it is bounded by the Republic of Benin. Ojo (1990) noted that the relief and drainage patterns of Lagos, generally, influence the coastal location of the study area. The coastal lowlands which dominate the Lagos landscape form part of a wider stretch of the coastal zone of southern Nigeria (Abegunde, 1976). According to Akanni and Ojo (1990), the mode of landform evaluation in Lagos has been largely influenced physico-climatic characteristics, which include; rainfall amount, intensity and distribution character of vegetation. They exert dominant influence upon the dynamics of coastal landform processes in the area. In understanding the landform types of Lagos, vegetation and soil types have served as important indications of the spatial pattern of the landform (Figure 2).

Geologically, Lagos area is situated on a series of stratified sedimentary rocks in the Dahomey Miogeosynclinal Basin of Southwestern Nigeria. These rocks comprise silt, clay, peat or coal and sands of various sizes and composition. Onwuka (1990) identified two broad geological formations in Lagos area, which are Ilaro Formation and Coastal Plain sands. The Quarternary Formation of the Coastal Plain sands is more widely spread over the study area (Figure 3).

\section{METHODS}

Geophysical and geotechnical methods were employed in this study covering some selected areas of Lagos based on the challenges posed by the nature of their subsurface formation. The geophysical equipment used is ABEM Terammeter SAS 300 model. Data acquisition involved VES, which made use of the Schlumberger array with $A B / 2$ varying from 1.0 to $50.0 \mathrm{~m}$ (that is, total current electrode spread of $100.0 \mathrm{~m}$ ). Data processing began with plots of apparent resistivity $\left(\sigma_{\mathrm{a}}\right)$ on the $y$-axis against electrode spacing $(A B / 2)$ on the $x$-axis in a log-log paper to obtain resistivity curves. These curves were interpreted using the partial curve matching techniques of Orellana and Mooney (1966); Mooney (1980) and Velpen (1988) with computer iteration using RESIST software.

Cone penetration test (CPT) were carried out at 5 locations in those selected areas, which include, Shomolu, Ebute Metta, Ikoyi, Eleko, Gbagada and Ajah. The penetrometer unit consists of a cone having an apex angle of $60^{\circ}$ and area of $10 \mathrm{~cm}^{2}$ with a winch as well as push rods for pushing cone into the ground, and pressure gauge that indicates penetration resistance in $\mathrm{Kg} / \mathrm{cm}^{2}$. 


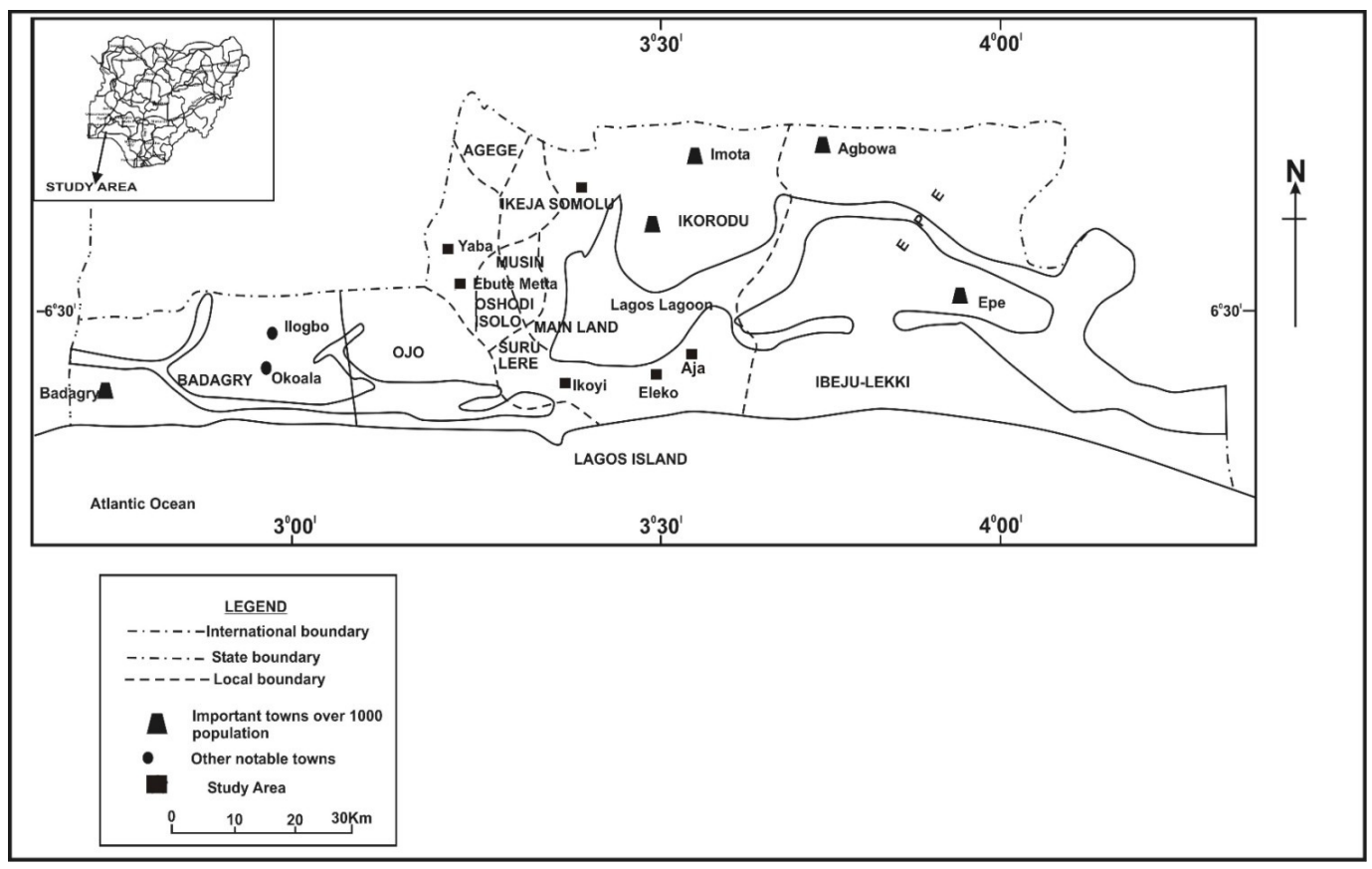

Figure 1. Generalised map of Lagos.

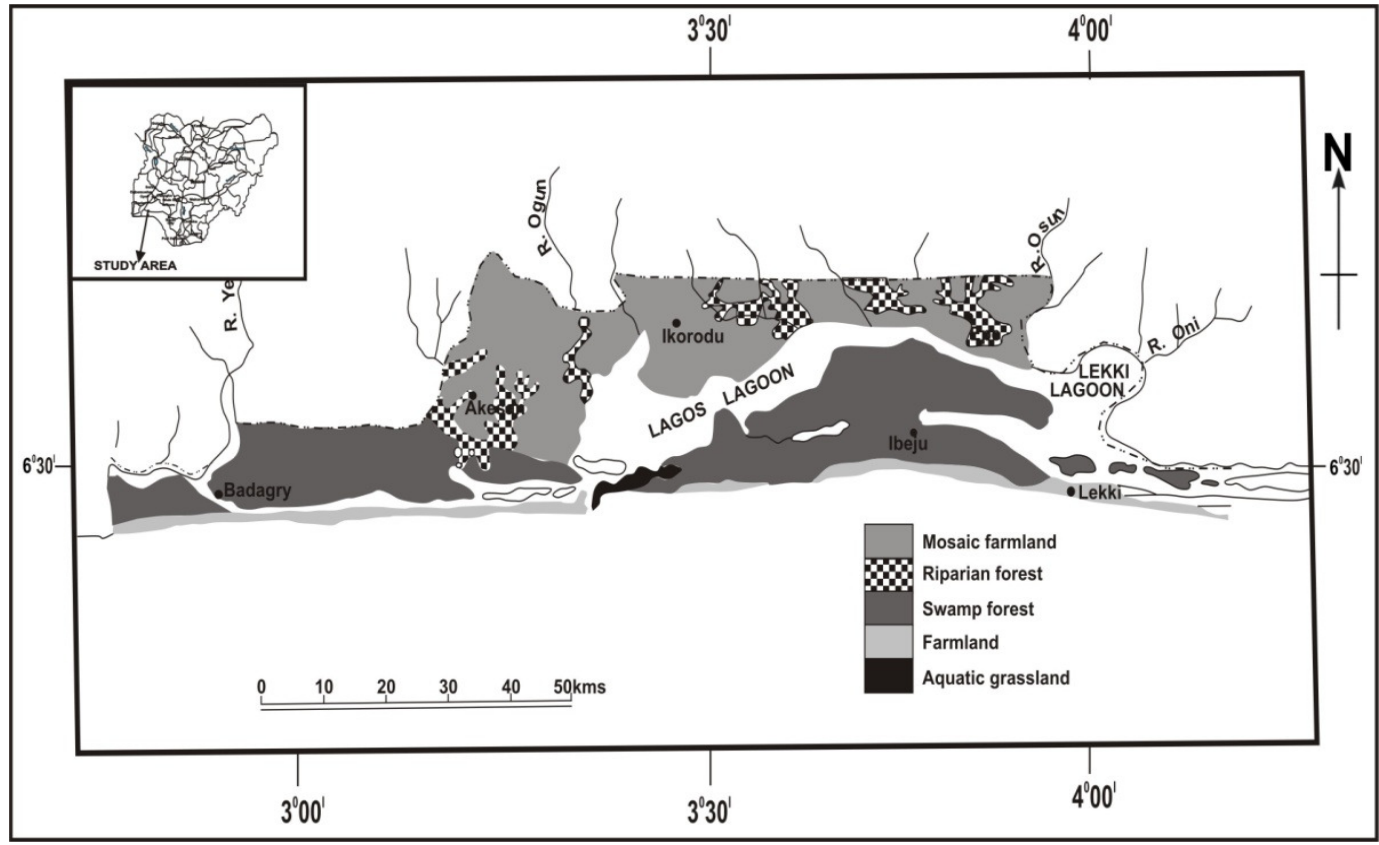

Figure 2. Map of vegetation distribution and drainage pattern of Lagos.

Plots of cone resistance against depth of penetration in metres were made to obtain point resistance-depth curves, while bearing values in $\mathrm{kN} / \mathrm{m}^{2}$ at depths of interest were estimated using Meyerhoff's formula $q_{a}=2.7 . q_{c}$. Where qa is the allowable bearing capacity expressed in $\mathrm{kN} / \mathrm{m}^{2}$, and $\mathrm{qc}$ is the cone resistance in $\mathrm{Kg} / \mathrm{cm}^{2}$.

\section{RESULTS}

The VES reveals that the geological conditions from Shomolu to Ajah are 2 to 5 layered soil types, and are summarized in Table 1. The first layer which has 


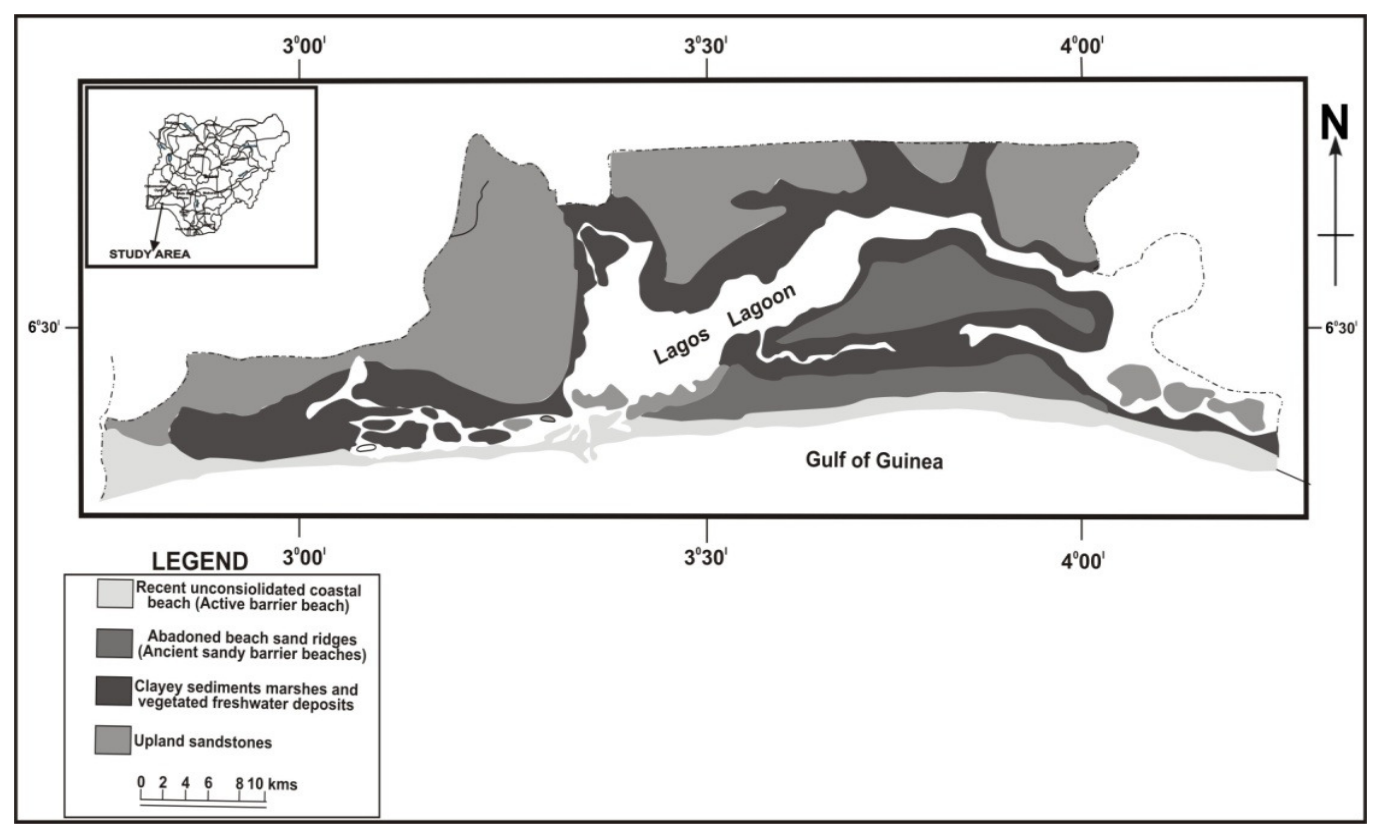

Figure 3. Map of surface geology and morphology of Lagos.

Table 1. Resistivity and layer thickness from VES data.

\begin{tabular}{lcccl}
\hline Location & Layers & Thickness $(\mathbf{m})$ & Resistivity $(\mathbf{\Omega m})$ & Interpretation \\
\hline \multirow{3}{*}{ Shomolu } & 1 & 0.94 & $41-163$ & Clay/Sandy Clay \\
& 2 & 1.5 & 1711 & Sand \\
& 3 & 4.7 & 41 & Organic Clay \\
& 4 & - & 78333 & Coarse Sand \\
Ebute Metta & 1 & 0.6 & 200 & Sand \\
& 2 & 0.2 & 8 & Organic Clay \\
& 3 & 2.2 & 76 & Clay \\
& 4 & - & 206 & Sand \\
Ikoyi & 1 & 1.8 & $39-84$ & Clay/Inorganic Clay \\
& 2 & 1.11 & 425 & Sand \\
& 3 & 4.7 & 46 & Organic Clay \\
& 4 & 0.5 & 1328 & Coarse Sand \\
& 5 & - & 100 & Sandy Clay \\
Eleko & 1 & 0.16 & 127 & Sandy Clay \\
& 2 & 4.3 & 294 & Sand \\
& 3 & 6.5 & 32 & Organic Clay \\
Ajah & 4 & - & 2302 & Coarse Sand \\
& 1 & 1.5 & $203-1084$ & Clayey sand \\
\hline
\end{tabular}

resistivity values ranging between 82 to $492 \Omega m$ corresponds to the top soil, comprising clayey sand. Its thickness ranges from 0.1 to $1.26 \mathrm{~m}$ throughout the study area. The second layer reflects deposition of recent sediment. It is made up of sand and organic clay, with resistivity range of 294 to $1084 \Omega \mathrm{m}$ in Ajah and Eleko, as well as resistivity range of 8 to $41 \Omega \mathrm{m}$ in other places. The third layer is mainly organic clay of 2.2 to $7.1 \mathrm{~m}$ 
Table 2. Generalised strata description of the study area from CPT data.

\begin{tabular}{|c|c|c|}
\hline Depth range $(m)$ & Strata description & Cone resistance $\left(\mathrm{Kg} / \mathrm{cm}^{2}\right)$ \\
\hline $0.25-1.75$ & Clay/inorganic clay/Clayey sand & $1.0-50.0$ \\
\hline $2.0-4.25$ & Organic clay/Sand & $2.0-107.0$ \\
\hline $4.5-9.75$ & Organic clay/Clay/Clayey sand & $12.0-250.0$ \\
\hline $10.0-13.75$ & Organic clay/Coarse sand & $10.0-160.0$ \\
\hline
\end{tabular}
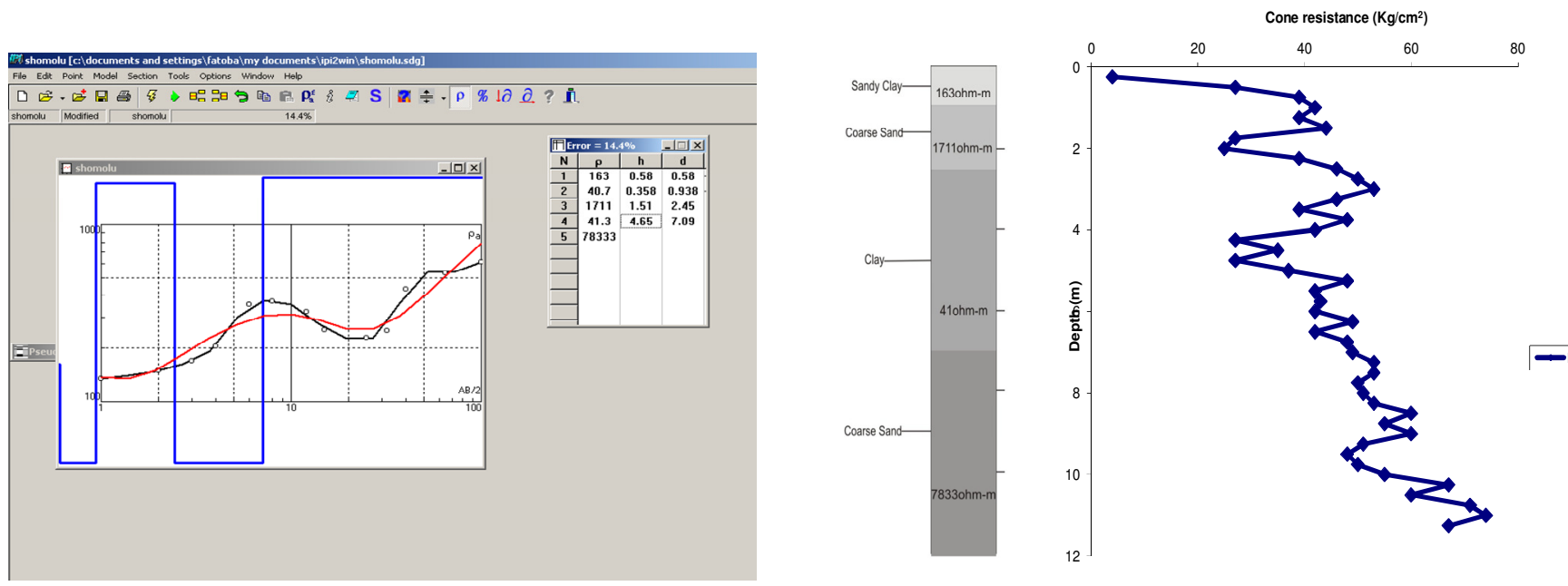

Figure 4. Resistivity curve, geoelectric section and penetration resistance at Shomolu.

thickness with resistivity range of 26 to $76 \Omega \mathrm{m}$. The fourth layer has resistivity range of 17 to $78333 \Omega \mathrm{m}$ is organic clay/coarse sand with thickness ranging between 0.5 and $1.1 \mathrm{~m}$. Results of penetrometer test are summarized in Table 2. On the basis of penetration resistance values, the strata compositions of the subsurface contain clayey sand with the exception of the formation below the depth of $10 \mathrm{~m}$ which contain coarse sand in addition. From CPT data, the first layer is $1.75 \mathrm{~m}$ thick with penetration resistance range of 1.0 to $50.0 \mathrm{Kg} / \mathrm{cm}^{2}$ where inorganic clay/clayey sand are inferred. The second and third layers are made up largely of organic clay and sand having maximum cone resistance of 107.0 to 250.0 $\mathrm{Kg} / \mathrm{cm}^{2}$, form depth of 2.0 to $4.25 \mathrm{~m}$, respectively.

\section{DISCUSSION}

Discussion of results for this study is limited to depth of $13.75 \mathrm{~m}$, which is adequate for foundation investigation as corroborated by Adeyemi and Osammor (2001). The VES curves generated so far are characteristic of an area underlain by stratified rocks. On the basis of resistivity values, various soil types that make up every layer in the subsurface formation are defined. The subsoils to a depth of about $13 \mathrm{~m}$, revealed 4 major geoelectric layers. The soil types range from sandy clay to organic clay.
Throughout the study area, only Eleko recorded $6.5 \mathrm{~m}$ thickness, while Shomolu and Ikoyi recorded the maximum thickness of $4.7 \mathrm{~m}$.

Figures 4 to 8 show correlations of geoelectric sections at each location with the corresponding penetration resistance in the study area. Although, both methods provided information about the soil types in the area however, the geoelectric sections revealed broad composite nature of the underlying strata, while the CPT curves furnished information about the lithology variability of the underlying soils. VES data obtained from this study, describing the stratified subsurface is consistent with findings of Koefoed (1979). Throughout the study area depths of 4.25 and $9.75 \mathrm{~m}$ displayed considerably high cone resistance. The allowable bearing capacities for foundations, irrespective of the width at those depths will be 288.9 and $675 \mathrm{kN} / \mathrm{m}^{2}$ in the organic clayey sand clayey coarse sandy formation. These values were estimated from Meyerhof's (1956) approximate formula.

Patterns displayed by both geoelectric section and the penetration-depth curves strongly defined the variation of the subsurface lithology in the study area. The portions of the underlying strata that are sandy show greater resistivity, and cone resistance than the portions of the strata that are clayey. Sand is known to be associated with high angle of internal friction and limited settlement, 

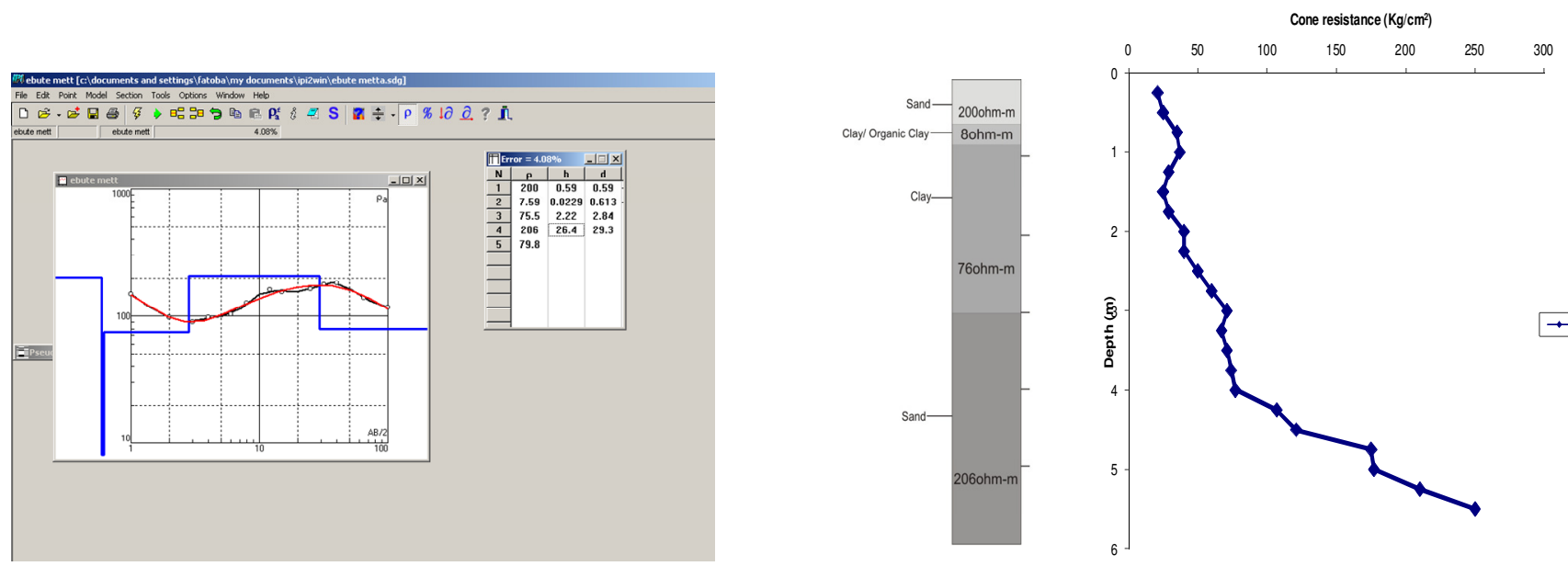

Figure 5. Resistivity curve, geoelectric section and penetration resistance at Ebute-Metta.
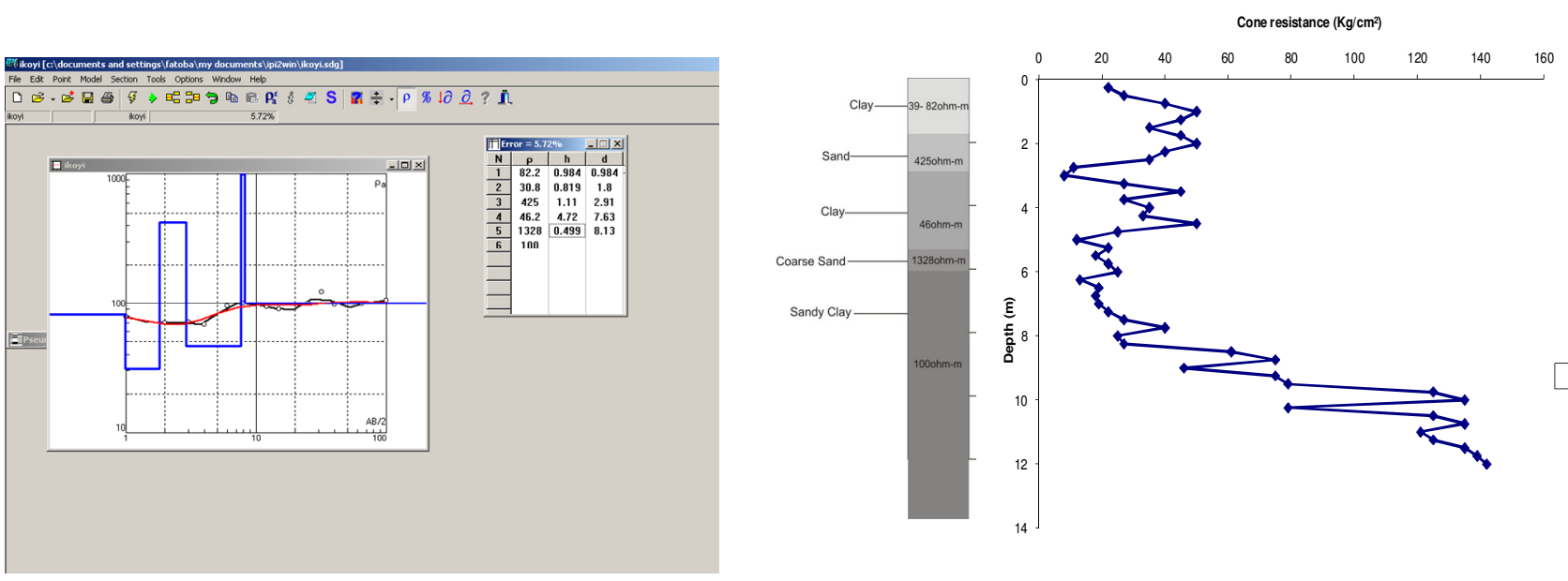

Figure 6. Resistivity curve, geoelectric section and penetration resistance at lkoyi.
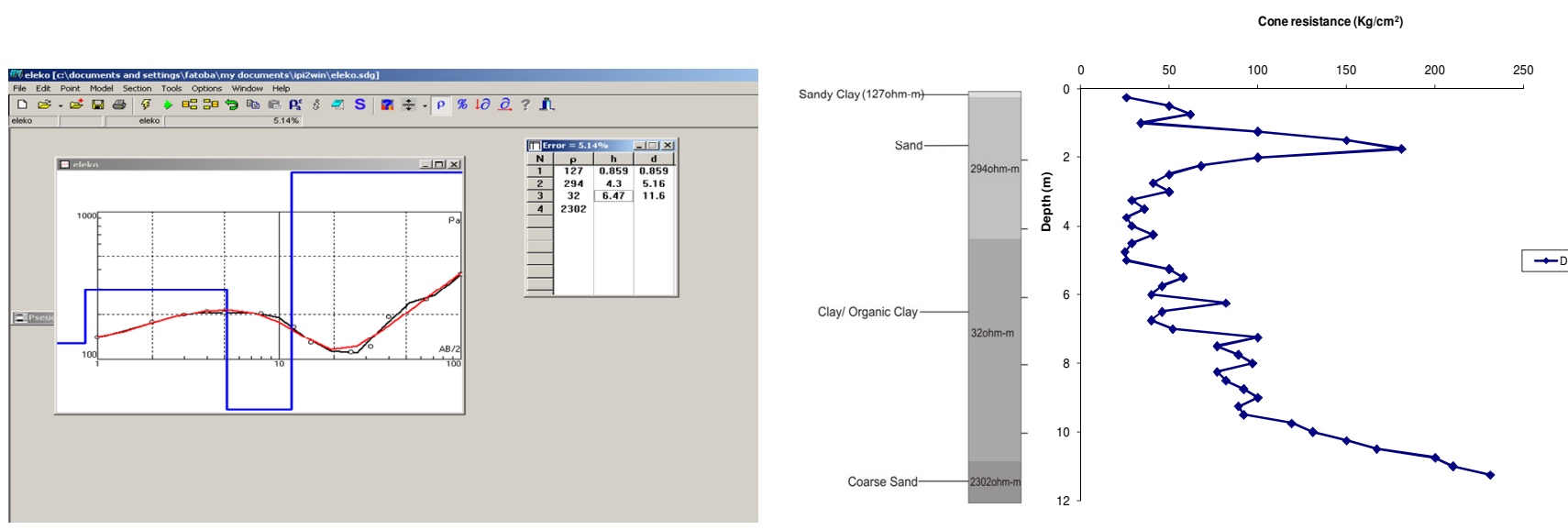

Figure 7. Resistivity curve, geoelectric section and penetration resistance at Eleko. 

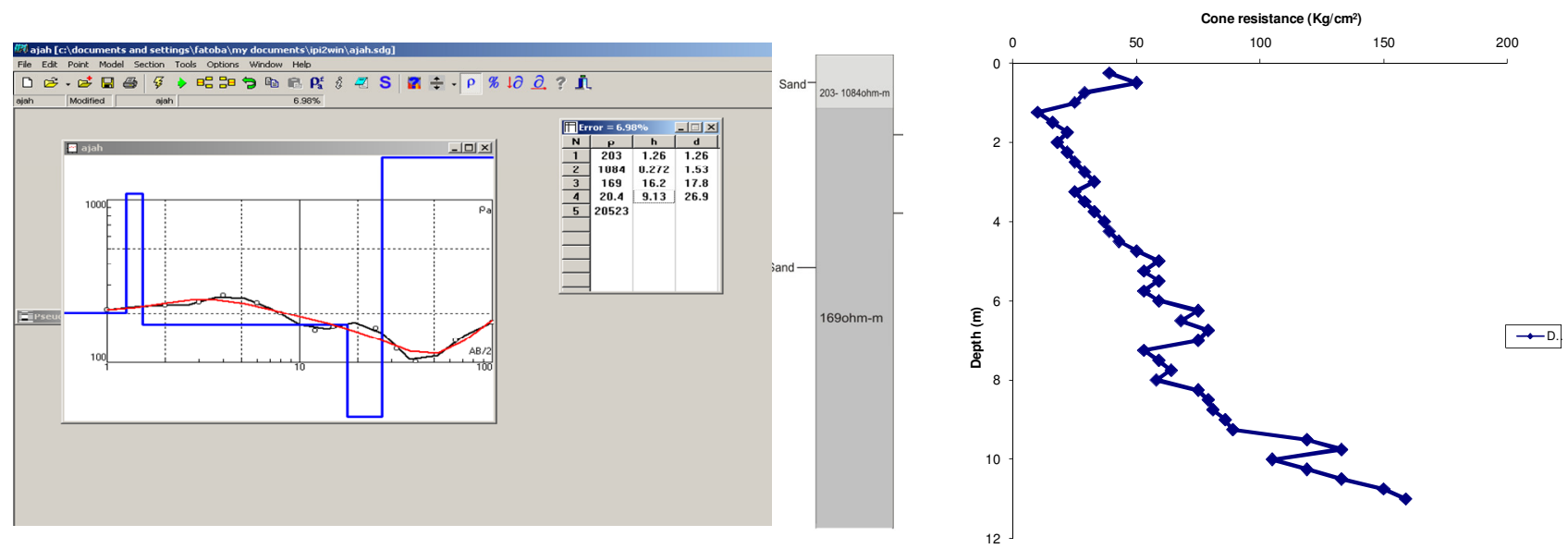

Figure 8. Resistivity curve, geoelectric section and penetration resistance in Ajah.

thus a shear failure is not likely occur at the specified depths.

\section{Conclusions}

The use of geophysical and geotechnical in-situ instruments made it possible to acquire information about the subsurface over a substantial area, and depth for near surface stratigraphy and in the determination of allowable bearing capacity at zones of interest to foundations. Method of cone penetrometer is of advantage over VES by revealing localized variations in the subsurface strata. Unlike the time-consuming laboratory methods which require boring of holes/pits, the equipment for in-situ methods are easily deployed and easily detect competent beds for structural loading.

\section{REFERENCES}

Abam TSK, Okogbue CO (1997). The cone penetrometer and soil Characterization in the Deltas. J. Min. Geol. 33(1):15-24.

Abam TSK, George EAJ (1997). Penetration testing in the highly stratified sediment of the Niger Delta. J. Min. Geol. 33(1):7-14.

Abegunde MAA (1976). The coastal lowlands around Lagos. Extract from staff seminar, University of Lagos.

Adebisi NO, Oloruntola MO (2005). Geophysical and geotechnical evaluation of foundation conditions of a site $n$ Ago-lwoye, Southwestern Nigeria. J. Min. Geol. 42(1):79-84.

Adeyemi GO, Osammor J (2001). In-situ geotechnical investigation of some soils in Southern Nigeria. J. Min. Geol. 37(1):69-76.

Akanni CO, Ojo AO (1990). Soils of Lagos state, in Lagos State in maps. Balogun, Y., Odumosu, T., and Ojo, K. Edited. Rex Charles and Connel Publications. pp. 228-229.

Carter M, Bentley SP (1991). Correlations of soil properties. Pentech. Press Publishers. London. http://library.wur.nl/WebQuery/isric/13314

Koefoed O (1979). Geosounding Principles 1. Resistivity Sounding Measurements. Elsevier, Amsterdam.
Meyerhof GG (1956). Penetration tests and bearing capacity of cohesionless soils. American Society of Civil Engineers. J. Soil Mech. Found. Eng. Div. 82:1-19.

Mooney HM (1980). Handbook of Engineering Geophysics. Vol. 2 Electrical resistivity Bison Instrument Inc.

Odumosu T (1992). Spatio-temporal analysis of metropolitan process. Unpublished Ph.D. Thesis, Dept. Geogr. Uni. Lagos.

Ojo AO (1990). The physical environment of Lagos, in Lagos State in maps. Balogun, Y., Odumosu, T., and Ojo, K. Edited. Rex Charles and Connel Publications. pp. 217-237.

Olayinka IA, Oyedele AA (2001). Geoelectrical investigation of sites along the proposed Ibadan-llorin dual carriageway. J. Min. Geol. 57(2):163-175.

Olorunfemi MO, Mesida ZA (1987). Engineering geophysics and its application in engineering site investigation - case study from lle Ife area. Niger. Eng. 22:57-66.

Olorunfemi MO, Ojo JS, Sonuga FA, Ajayi O, Oldipo MI (2000). Geoelectric and electromagnetic investigation of the failed Koza and Nassarawa earth dams around Kastina, Northern Nigeria. J. Min. Geol. 36:51-65.

Onwuka MO (1990). Ground water resources of Lagos. M.Sc. dissertation, Geol. Dept., U.I.

Orellana E, Mooney HM (1966). Master tables and curves for Vertical ElectricalSounding over layered structures. Interientia, Madrid, Spain.

Oyedele KF, Okoh C (2011). Subsoil investigation using integrated methods at Lagos, Nigeria. J. Geol. Min. Res. 3(7):169-179.

Oyedele KF, Olorode O (2010). Site ivestigations of subsurface conditions using electrical resistivity method and Cone Penetration Test at Medina Estate, Gbagada, Lagos, Nigeria. World Appl. Sci. J. 11(9):1097-1104.

Velpen BPA (1988). A computer processing package for D.C. Resisvity interpretation For an IBM compatibles. The Natherlands ITC J. pp. 14. 


\section{APPENDIX}

\begin{tabular}{|c|c|c|c|c|c|c|c|}
\hline Depth (m) & Eleko (CPT) & Ikoyi (CPT) & Shomolu (CPT) & Yaba (CPT) & Ebute metta (CPT) & Ajah (CPT) & Gbagada (CPT) \\
\hline 0.25 & 26 & 22 & 4 & 0 & 21 & 39 & 1 \\
\hline 0.5 & 50 & 27 & 27 & 21 & 25 & 50 & 2 \\
\hline 0.75 & 62 & 40 & 39 & 25 & 35 & 29 & 3 \\
\hline 1 & 34 & 50 & 42 & 29 & 37 & 25 & 4 \\
\hline 1.25 & 100 & 45 & 39 & 33 & 29 & 10 & 5 \\
\hline 1.5 & 150 & 35 & 44 & 32 & 25 & 16 & 5 \\
\hline 1.75 & 181 & 45 & 27 & 38 & 29 & 22 & 5 \\
\hline 2 & 100 & 50 & 25 & 47 & 40 & 18 & 6 \\
\hline 2.25 & 68 & 40 & 39 & 37 & 40 & 22 & 8 \\
\hline 2.5 & 50 & 35 & 46 & 38 & 50 & 25 & 6 \\
\hline 2.75 & 41 & 11 & 50 & 47 & 60 & 29 & 7 \\
\hline 3 & 50 & 8 & 53 & 54 & 71 & 33 & 4 \\
\hline 3.25 & 29 & 27 & 46 & 50 & 67 & 25 & 11 \\
\hline 3.5 & 36 & 45 & 39 & 49 & 71 & 29 & 12 \\
\hline 3.75 & 26 & 27 & 48 & 50 & 74 & 33 & 22 \\
\hline 4 & 29 & 35 & 42 & 59 & 77 & 37 & 10 \\
\hline 4.25 & 41 & 33 & 27 & 67 & 107 & 39 & 19 \\
\hline 4.5 & 29 & 50 & 35 & 63 & 121 & 43 & 17 \\
\hline 4.75 & 25 & 25 & 27 & 69 & 175 & 50 & 14 \\
\hline 5 & 26 & 12 & 37 & 71 & 177 & 59 & 12 \\
\hline 5.25 & 50 & 22 & 48 & 79 & 210 & 53 & 13 \\
\hline 5.5 & 58 & 18 & 42 & 81 & 250 & 59 & 100 \\
\hline 5.75 & 46 & 22 & 43 & 77 & & 53 & 100 \\
\hline 6 & 40 & 25 & 42 & 89 & & 59 & 106 \\
\hline 6.25 & 82 & 13 & 49 & 108 & & 75 & 111 \\
\hline 6.5 & 46 & 19 & 42 & 121 & & 68 & 119 \\
\hline 6.75 & 40 & 18 & 48 & 128 & & 79 & 125 \\
\hline 7 & 52 & 19 & 49 & 150 & & 75 & 131 \\
\hline 7.25 & 100 & 22 & 53 & 166 & & 53 & 135 \\
\hline 7.5 & 77 & 27 & 53 & 170 & & 59 & 137 \\
\hline 7.75 & 89 & 40 & 50 & 181 & & 64 & 140 \\
\hline 8 & 97 & 25 & 51 & & & 58 & 143 \\
\hline 8.25 & 77 & 27 & 53 & & & 75 & 144 \\
\hline 8.5 & 82 & 61 & 60 & & & 79 & 146 \\
\hline 8.75 & 92 & 75 & 55 & & & 81 & 148 \\
\hline 9 & 100 & 46 & 60 & & & 86 & 149 \\
\hline 9.25 & 89 & 75 & 51 & & & 89 & 151 \\
\hline 9.5 & 92 & 79 & 48 & & & 119 & 156 \\
\hline 9.75 & 119 & 125 & 50 & & & 133 & 158 \\
\hline 10 & 131 & 135 & 55 & & & 105 & 160 \\
\hline 10.25 & 150 & 79 & 67 & & & 119 & \\
\hline 10.5 & 167 & 125 & 60 & & & 133 & \\
\hline 10.75 & 200 & 135 & 71 & & & 150 & \\
\hline 11 & 210 & 121 & 74 & & & 159 & \\
\hline 11.25 & 231 & 125 & 67 & & & & \\
\hline 11.5 & & 135 & 69 & & & & \\
\hline 11.75 & & 139 & 75 & & & & \\
\hline 12 & & 142 & 78 & & & & \\
\hline 12.25 & & & 100 & & & & \\
\hline 12.5 & & & 101 & & & & \\
\hline
\end{tabular}



J. Geol. Min. Res.

Appendix. Contd.

$\begin{array}{cc}12.75 & 100 \\ 13 & 111 \\ 13.25 & 120 \\ 13.5 & 150\end{array}$

00

120

150 